E-Prodenta Journal of Dentistry. 2019. 3(1): 216-224

DOI : http://dx.doi.org/10.21776/ub.eprodenta.2019.003.01.5

\title{
EKSPRESI RANKL PADA DEFEK TULANG DENGAN PEMBERIAN XENOGRAFT DIBANDINGKAN DENGAN XENOGRAFT DAN PRF
}

\author{
Khusnul Munika Listari*, Iwan Ruhadi**, Noer Ulfa** \\ *Departemen Periodonsia ,Fakultas Kedokteran Gigi, Universitas Brawijaya \\ ${ }^{* *}$ Departemen Periodonsia ,Fakultas Kedokteran Gigi, Universitas Airlangga \\ Korespondensi :Khusnul Munika Listari, E-mail : khusnulmunika@gmail.com
}

\begin{abstract}
ABSTRAK
Defek tulang merupakan salah satu manifestasi klinis terjadinya periodontitis dimana pada kondisi tersebut terjadi inflamasi pada jaringan periodontal. RANKL adalah salah satu reseptor pada permukaan osteoblast yang level ekspresinya akan mengalami peningkatan ketika terjadi inflamasi sehingga dapat merangsang osteoclastgenesis yang mengakibatkan resorbsi/defek tulang alveolar. PRF merupakan fibrin matriks generasi terbaru dari platelet concentrate yang didalamnya terdapat growth factor yang bisa mendukung terjadinya regenerasi tulang Tujuan: Tujuan dari penelitian ini adalah untuk mengetahui perbedaan ekspresi RANKL pada defek dengan pemberian xenograft dibandingkan dengan pemberian xenograft+PRF. Metode: delapan belas kelinci New Zealand jantan dibagi menjadi 3 kelompok yaitu Kelompok 1 (pemberian Xenograft), kelompok 2 ( pemberian PRF) dan kelompok 3 ( pemberian xenograft+PRF ). Defek tulang dibuat pada tulang tibia kelinci (kedalaman $3 \mathrm{~mm}$ dan diameter $5 \mathrm{~mm}$ ) kemudian diaplikasikan bahan penelitian pada defek. Setelah 30 hari sampel jaringan diambil dan dilakukan pewarnaan imunohistokimia untuk mengetahui ekspresi RANKL. Hasil: Ekspresi RANKL terbanyak terdapat pada kelompok 1 kemudian diikuti oleh kelompok 2 dan kemudian kelompok 3 (paling sedikit). Terdapat perbedaan signifikan antara kelompok satu dibandingkan dengan kelompok 2 dan 3. Kesimpulan: Aplikasi xenograft+PRF pada defek memiliki kemampuan osteogenesis yang lebih baik dibandingkan hanya xenograft saja.
\end{abstract}

Kata kunci: RANKL, Xenograft, PRF, Defek tulang 


\title{
EXPRESSION OF RANKL ON BONE DEFECT BY APPLICATION XENOGRAFT COMPARED TO XENOGRAFT AND PRF
}

\begin{abstract}
Bone defect is one of the clinical manifestation of periodontitis where in inflammation occurs in the periodontal tissue. RANKL is one of receptor which is found in the surface of osteoblast whose level will increase when inflammation occurs thereby stimulating osteoclastgenesis which can cause bone defect/bone resorbtion. PRF is the lastest generation of fibrin matriks from platelet concentrate in which a growth factor that can support bone regeneration. Aim: The aim of this study was to know the differentiation expression of RANKL on bone defect by application xenograft compare to xenograft and PRF. Methods: eighteen new zealand rabbits were divided to three groups. Group 1 (application xenograft), group 2 (application PRF) and group 3(application xenograft+PRF). Bone defect was made in rabbits tibia bone (depth $3 \mathrm{~mm}$ and diameter $5 \mathrm{~mm}$ ) and those material was applicated on the defect. After 30 day, sample was taken. Then imunohistokimia stainning was done to be know the expression of RANKL Result: The highest number expression of RANKL be found in group 1 followed by group 2 and then group 3 at least. There are significant differentiation Between group 1 compared to group 2 and group 3. Conclusion: Application of Xenograft+PRF in bone defect has better osteogenesis ability compared to xenograft only.
\end{abstract}

Keywords: RANKL, Xenograft, PRF, Bone defect

\section{PENDAHULUAN}

Penyebab paling sering dari kerusakan atau defek tulang pada penyakit periodontal adalah adanya perluasan inflamasi dari margin gingiva menuju jaringan yang lebih dalam lagi. Ketinggian dan kepadatan tulang alveolar secara normal dipengaruhi oleh suatu keadaan homeostasis dari bone formation dan bone resorption yang diregulasi oleh keadaan lokal dan sistemik. Ketika bone resorption berlebih dibandingkan dengan bone formation maka ketinggian dan kepadatan tulang bisa berkurang. Tujuan dari perawatan penyakit periodontal adalah untuk mengembalikan kesehatan dan fungsi dari jaringan periodontal. Perawatan konvensional seperti skeling, root planing dan bedah periodontal saja terkadang kurang memiliki efek maksimal terhadap regenerasi jaringan periodontal sehingga diperlukan suatu bahan khusus yang memiliki kemampuan dalam mendukung proses tersebut. $^{12}$

Selama respon inflamasi, sitokin, chemokine dan mediator pro inflamatory menstimulasi periosteal osteoblast sehingga merubah level receptor activator of nuclear factor-kappa $B$ ligand (RANKL) pada permukaan osteoblast. Jika respon inflamasi meningkat 
maka level RANKL akan meningkat dan akan lebih banyak daripada osteoprotegerin (OPG) , hal ini mengakibatkan terjadinya perlekatan antara RANKL dan RANK ( receptor activator of nuclear factor-kappa $B$ ) yang bisa merangsang terjadinya osteoclastgenesis dan mengakibatkan resorbsi tulang.$^{34}$

Bone graft adalah materi yang digunakan bersama-sama dengan flap periodontal, yang diharapkan membantu terjadinya pertumbuhan tulang melalui proses osteogenesis, osteoinduksi atau osteokonduktif - Penggunaaan Bone graft adalah sebagai bahan pengisi dan scaffolds di dalam defek tulang untuk mendukung terjadinya regenerasi tulang alveolar dan membantu mempercepat proses healing. Bone graft bersifat bioresorbable, tidak memiliki reaksi antigen dan antibodi serta berperan sebagai sumber mineral yang berfungsi untuk menginduksi terjadinya pembentukan tulang baru. Salah satu tipe bone graft yang sering dipergunakan dalam praktek sehari-hari adalah xenograft. Xenograft adalah graft yang didapatkan dari spesies yang berbeda dari resipien. Xenograft memiliki sifat nonimunogenik dan dapat diganti oleh tulang manusia dalam waktu 4 sampai 24 minggu .567

Platelet rich fibrin ( PRF ) adalah generasi terbaru dari platelet concentrate, merupakan fibrin matriks yang didalamnya terdapat platelet cytokines dan growth factor, tidak menyebabkan immune rejection oleh tubuh karena didapat dari pembuluh darah vena penderita sendiri . Bentuk PRF adalah gel, dapat digunakan bersama dengan bonegraft ataupun sebagai membran, pembuatan PRF sangat mudah dan sederhana serta tidak memerlukan penambahan trombin ataupun koagulan. PRF mengandung growth factor antara lain yaitu platelet derived growth factor (PDGF), tranforming growth factor- $\beta$ (TGF- $\beta$ ), vascular endothelial growth factor (VEGF), insulin like growth factor (IGF), dan epidermal growth factor (EGF), platelet factor 4 dan matriks glikoprotein seperti fibronectin dan vitronectin yang berperan sebagai protein kunci untuk cell-matrix contact. semua komponen diatas memiliki fungsi berbeda-beda tetapi saling mendukung untuk terjadinya regenerasi tulang dan jaringan lunak. PRF memiliki banyak manfaat antara lain adalah mempercepat penyembuhan, pertumbuhan dan maturasi tulang, graft stabilization dan meningkatkan kualitas graft material .8 910

Beberapa penelitian telah melaporkan bahwa PRF memiliki kemampuan dalam mendukung regenerasi baik pada jaringan keras atau jaringan lunak. Akan tetapi penelitian tentang penggunaan bone graft bersama dengan PRF dalam suatu defek tulang terhadap penurunan level ekspresi RANKL dimana hal tersebut akan meningkatkan dan mempercepat proses osteogenesis belum pernah dibuktikan sebelumnya.

\section{METODE}

Penelitian ini merupakan jenis penelitian ekperimental laboratoris dan dilakukan di laboratorium Biokimia FK Unair. Subyek penelitian menggunakan hewan coba kelinci New Zealand jantan yang berjumlah 18 ekor. Dilakukan randomisasi 18 ekor kelinci dan 
dibagi menjadi 3 kelompok yaitu kelompok 1,2 dan 3. Semua kelompok dilakukan adaptasi 1 minggu, sebelum dilakukan pembuatan defek tulang pada kelompok 2 dan 3 diambil sampel darah pada bagian telinga kelinci untuk pembuatan PRF. Pembuatan defek dilakukan dengan cara mengebur di bagian tungkai tibia belakang kanan hewan coba menggunakan bur tulang dengan ukuran diameter $5 \mathrm{~mm}$ dan kedalaman 3mm. Defek yang sudah terbentuk pada masing masing kelompok diberi perlakuan sebagai berikut: kelompok 1 di diberi xenograft saja, Kelompok 2 diberi PRF saja dan pada kelompok 3 diberi xenograft+PRF. Masingmasing kelompok diambil sampel jaringan dan dikorbankan setelah 30 hari.

PRF disiapkan dari $5 \mathrm{ml}$ darah yang diambil dari tiap-tiap hewan coba. Persiapan PRF harus steril, darah akan dimasukkan dalam tabung plastik melewati dinding tabung dengan perlahan tanpa anti koagulan. Tabung tersebut diputar dengan putaran standard selama 10 menit pada $2500 \mathrm{rpm}$ untuk membentuk Platelet Rich Fibrin (PRF). Akan tampak 3 lapisan, yaitu yang pertama adalah PPP, kedua berisi gumpalan PRF dan lapisan bawah berisi sel darah merah. Lapisan tengah diambil untuk mendapatkan PRF dengan menggunakan pinset lalu gunting perbatasan PRF dengan sel darah merah kemudian ditaruh kedalam saringan. PRF digunting kecil-kecil dan dicampur dengan xenograft.

Kelinci new zealand jantan dianastesi dengan penyuntikan ketamine secara intramuskular $15-25 \mathrm{mg} / \mathrm{kg} \mathrm{BB}$, ditunggu sampai kelinci lemas tertidur. Kemudian bulu pada daerah tibia kanan kelinci dihilangkan agar memudahkan insisi. Kemudian dilakukan anastesi dengan pehacaine pada tungkai belakang kelinci sebelah kanan. Insisi dilakukan memanjang pada tungkai kaki belakang kanan kelinci, dengan rasparatorium dilakukan pemisahan jaringan kulit dan tulang, kemudian dilanjutkan dengan pembuatan defek tulang pada masing-masing kelompok. Tindakan selanjutnya pada masing-masing defek adalah pada kelompok 1, diberikan xenograft 0,05gram ), Pada kelompok 2 diberikan PRF ( 0,05 gram ), dan pada kelompok 3 diberikan xenograft+PRF ( masing-masing 0,025 gram). Luka kemudian dijahit, lapisan dalam menggunakan cat gut dan lapisan luar menggunakan benang silk, lalu luka ditutup dengan hypafix, setelah 2 minggu dilepas jahitan luarnya. Pada kelompok 1,2, dan 3 ditunggu 30 hari untuk kemudian hewan dikorbankan dan diambil sampel jaringanya. Dilakukan pewarnaan imunohistokimia pada sampel jaringan dengan tujuan untuk melihat ekspresi RANKL yang terbentuk.

\section{HASIL}

Pada gambar 1 bisa dilihat ekspresi RANKL pada pewarnaan imunohistokimia. Pemeriksaan dan perhitungan RANKL diamati ekspresinya dengan melihat adanya warna coklat pada sitoplasma sel. ${ }^{11}{ }^{12}$ Pada kelompok 1 terlihat ekspresi RANKL lebih banyak apabila dibandingkan dengan kelompok 2 dan 3.

Rata-rata dan standar deviasi hasil penghitungan ekspresi RANKL terlihat pada tabel 1. 

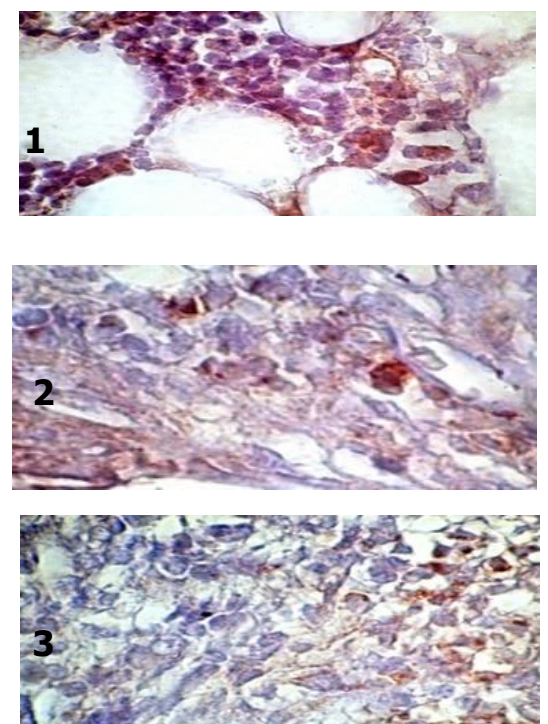

Gambar 1. Ekspresi RANKL hari ke-30. (Pembesaran 1000 X). No.1: kelompok xenograft, No.2: kelompok PRF, No.3: kelompok xenograft+PRF

Tabel 1. Rata-rata dan standar deviasi hasil penghitungan ekspresi RANKL

\begin{tabular}{llll}
\hline kelompok & Jml & Rata- & Standar \\
& samp & rata & Deviasi \\
& el & & \\
& & &
\end{tabular}

\begin{tabular}{|c|c|c|c|}
\hline $\begin{array}{l}\text { Xenograft ( } \\
\text { kel 1) }\end{array}$ & 6 & 11.43 & 2.149 \\
\hline PRF(kel 2) & 6 & 6.67 & 1.211 \\
\hline $\begin{array}{l}\text { Xenograft+ } \\
\text { PRF (kel 3) }\end{array}$ & 6 & 4.33 & 1.033 \\
\hline
\end{tabular}

Untuk mengetahui apakah hasil data penelitian homogen dilakukan levene test dan hasilnya menunjukkan nilai $p>0.05$ yang artinya data pada penelitian ini homogen. Selanjutnya untuk mengetahui apakah ada perbedaan yang bermakna pada masingmasing kelompok sampel, dilakukan one way anova test dimana didapatkan nilai $\mathrm{p}<0.05$, hal ini menunjukan adanya perbedaan yang bermakna pada ketiga kelompok perlakuan tersebut, sehingga dapat dikatakan bahwa pemberian PRF pada defek memiliki pengaruh terhadap ekspresi RANKL.

Untuk mengetahui kelompok mana saja yang terdapat perbedaan bermakna maka dilanjutkan dengan Tukey HSD Test. Berdasarkan hasil Tukey HSD Test dapat dilihat antara kelompok 2 (PRF) dan kelompok 3 (xenograft+PRF) didapatkan nilai $\mathrm{p}>0.05$, hal ini menunjukan bahwa antara dua kelompok tersebut tidak terdapat perbedaan yang bermakna. Akan tetapi pada kelompok 1 (xenograft) bila dibandingkan dengan kelompok 2 (PRF) atau kelompok 3 (xenograft+PRF) didapatkan nilai $p<0.05$, hal ini menunjukan bahwa terdapat perbedaan bermakna antara kelompok satu dibandingkan dengan dua kelompok lainya ( kelompok 2 dan 3 ).

Bila dilihat dari rata-rata hasil penghitungan ekspresi RANKL pada tiap-tiap kelompok memang berbeda, pada kelompok 1 (xenograft) ekspresi RANKL terbanyak diikuti dengan kelompok 2 ( PRF) dan paling sedikit adalah kelompok 3 (xenograft + PRF ). Berdasarkan uji statistik hanya kelompok xenograft yang memiliki perbedaan bermakna dengan kelompok PRF dan xenograft+PRF. Antara kelompok PRF dan xenograft+PRF tidak memiliki perbedaan yang bermakna.

\section{DISKUSI}

Resorbsi tulang alveolar pada penyakit periodontal diinisiasi oleh keberadaan 
osteoklas. Keseimbangan antara resorbsi tulang yang diinisiasi oleh osteoklas dan formasi/pembentukan tulang yang diinisiasi oleh osteoblas menentukan ketinggian dan kepadatan tulang. RANKL dan reseptornya yaitu RANK, serta OPG merupakan molekul kunci dalam regulasi, pengerahan dan fungsi dari osteoklas. RANKL diperlukan sebagai kunci untuk diferensiasi dari osteoclast precursor cells yang berperan dalam terjadinya resorbsi tulang. ${ }^{13}$ Beberapa penelitian melaporkan bahwa remodeling tulang bergantung pada rasio dari RANKL dan OPG. Jika ekspresi RANKL tinggi maka resorbsi tulang akan terjadi, sebaliknya jika ekspresi OPG yang lebih tinggi maka formasi/pembentukan tulang yang akan mendominasi. Pengikatan RANKL pada reseptor RANK dipermukaan pre-osteoblas menyebabkan aktivasi jun terminal kinase dan aktivasi nuclear factor-kappaB, yang mengarah pada pembentukan osteoklas. Osteoprotegerin merupakan inhibitor alami dari RANKL. Komponen ini merupakan molekul yang menyerupai reseptor tumor nekrosis faktor yang bertindak sebagai pengikat dan penghambat ikatan RANKL ke RANK sehingga dapat mencegah osteoclastogenesis. Osteoprotegerin dihasilkan oleh sel ligamen periodontal manusia, sel fibroblast gingiva dan sel epithelial dan ekspresinya dimodulasi oleh sel inflamasi sitokin. ${ }^{14}$

Penelitian ini dilakukan untuk mengetahui perbedaan ekspresi RANKL dengan mengaplikasikan xenograft+PRF, PRF dan xenograft saja pada defek tulang. Hasil penelitian menunjukan bahwa ekspresi RANKL menunjukkan level terendah pada aplikasi xenograft+PRF (kelompok 3) kemudian diikuti dengan aplikasi PRF saja ( kelompok 2) dan ekspresi RANKL terbanyak terlihat pada aplikasi xenograft saja ( kelompok 1). Setelah dilakukan uji statistik memang terdapat perbedaan yang bermakna antara kelompok 2 dan 3 jika dibandingkan dengan kelompok 1. Pada kelompok xenograft+PRF ( kelompok 3 ) terdapat ekspresi RANKL paling sedikit dibandingkan kelompok lainya, hal ini menunjukan bahwa pada kelompok 3 terjadi proses regenerasi tulang yang lebih baik dibandingkan dengan kelompok lainya.

Penggunaan bonegraft khususnya xenograft pada penelitian ini dilakukan karena bahan ini telah banyak digunakan untuk perbaikan cacat tulang, yang disebabkan oleh trauma, reseksi oleh karena tumor, degenerasi oleh karena proses patologis, dan cacat tulang bawaan ataupun periodontitis. Xenograft digunakan dengan tujuan bisa membantu terjadinya regenerasi tulang melalui proses osteokonduksi. Pada tahap awal setelah bone graft diaplikasikan pada defek tulang, maka akan terjadi gumpalan bone graft yang dibungkus oleh darah kemudian pada hari ke-7 akan terjadi respon inflamasi akut dengan invasi sel neutrofil, limfosit, dan sel plasma. Proses inflamasi yang terjadi menyebabkan aktifasi sel premesenchymal, growth factor dalam darah dan mediator inflamasi yang dapat menyebabkan sel premesenchymal berdeferensiasi menjadi osteoblast sehingga akan terjadi pembentukan tulang, kemudian 
terjadi penyatuan bone graft dengan tulang host. ${ }^{15}$

PRF adalah suatu autologous healing biomateria/dimana di dalamnya terdapat matrix dari autologous fibrin yang terdiri dari leukosit, platelet dan growth factor yang didapatkan dari sampel darah. ${ }^{16}$ Pemakaian PRF pada defek dalam penelitian ini mencoba membuktikan bahwa PRF bisa mempercepat regenerasi tulang dan hal ini terbukti terutama pada aplikasi xenograft + PRF pada defek yang menunjukan level ekspresi RANKL terkecil dibandingkan kelompok lainya. Hal ini sesuai dengan penelitian terdahulu oleh Chang yang menyebutkan bahwa PRF memiliki kemampuan dalam meningkatkan extra cellular signal protein kinase ( $p-E R K)$, menstimulasi produksi osteoprotegerin (OPG) dan meningkatkan alkaline phosphatase (ALP) sehingga dapat menstimulasi diferensiasi dan proliferasi dari osteoblas yang dapat mendukung dalam proses pembentukan tulang. ${ }^{17}$ Pada penelitian sebelumnya juga dilaporkan bahwa penggunaan PRF pada defect cranial pada kelinci menunjukkan ekspresi VEGF dalam konsentrasi tinggi, hal ini dipercaya bahwa menjadikan regulasi angiogenesis menjadi lebih baik . Angiogenesis merupakan hal yang penting dalam proses healing jaringan karena pembentukan pembuluh darah baru ini mendukung suplai oksigen, nutrisi dan sel sel yang diperlukan pada jaringan yang mengalami perlukaan sehingga diharapkan terjadi proses regenerasi jaringan. ${ }^{18}$ Dalam penelitianya Marx juga mengevaluasi efek dari PRP ( autologous platelet generasi lama sebelum PRF dengan kandungan yang kurang lebih sama dengan PRF) yang dikombinasi dengan bone graft pada mandibular continuity defects, PDGF dan TGF- $\beta$ yang berasal dari platelet bisa mengabsorbsi ke dalam graft sehingga bisa meningkatkan kualitas dari graft sehingga bisa mendukung bone formation.$^{19}$

Beberapa penelitian lain juga menyebutkan bahwa penambahan PRF bisa mengurangi banyak efek merugikan pada sisi inflamasi pada bagian luka dengan meregulasi kerusakan dan racun yang berlebihan yang ditimbulkan oleh proses healing pada jaringan yang luka, hal ini dikarenakan PRF memiliki efek immune regulation node dengan kemampuan inflammation retro-control dan pengurangan infeksi post operative. Dengan terkontrolnya inflamasi akan dapat menghambat ekspresi RANKL yang berlebih dimana hal ini bisa memberikan efek yang bagus yakni dengan menghambat osteoclasgenesis yang berlebih sehingga bisa terjadi bone formation. 2021

Pada penelitian ini, hasil paling baik terdapat pada kelompok xenograft+PRF (kelompok 3) yang menunjukan ekspresi RANKL terkecil,dapat diambil kesimpulan bahwa pada kelompok 3 terjadi proses regenerasi tulang paling bagus dibanding kelompok lainya. Hal ini sesuai dengan penelitian Anitua yang menyatakan bahwa Bone graft dan alveolar ridge augmentation masih tetap digunakan sebagai salah satu cara untuk meningkatkan densitas tulang, akan tetapi penambahan autologous platelet mampu memberikan hasil yang lebih baik. ${ }^{22}$ 


\section{KESIMPULAN}

Aplikasi xenograft+PRF pada defek memiliki kemampuan osteogenesis yang lebih baik dibandingkan hanya pemberian xenograft saja.

\section{DAFTAR PUSTAKA}

1. Nie Li et al. The healing of alveolar bone defects with novel bio-implants composed of Ad-BMP9-transfered rDFCS and CHA scaffolds. Sci rep. 2017; 7: 6373.

2. Newman. MG, Takei HH, Carranza FA. Clinical Periodontology. 12th edition. Philadelphia: Elsevier Saunders; 2015.

3. Cochran DL. Inflammation and Bone Loss in Periodontal Disease. J Periodontol. 2008; 79(1): p.569-1576.

4. Kapasa R E et al. The Effect Of RANKL/OPG Balance On Reducing implant Complication. J.Funct.Biomater. 2017; 8: 42.

5. Chun $\mathrm{R}$, Effect of growth factor on the Osteoinductive Potential of Hidroxyapatite $\beta$-Tricalcium Phospate (HA-TCP), A report Submitted to the Univercity of Adelaide in partial fillfilment $o$ the requirement of the Degree of Doctor of Clinical Dentistry. The Univercity of Adelaide. 2009.

6. Kumar $\mathrm{P}$ et al. Bonegraft In Dentistry. Journal of Pharmacy \& Bioallied Science. 2013; 5(Suppl 1): S125-S127.

7. Sukumar S. Bonegraft in periodontal. Therapyacta Medica (Hradec Kralove). 2008; 51(4): 203-207.

8. Borie $\mathrm{E}$ et al. Platelet-rich Fibrin application in dentistry : a literature review. Int J Clin Expp Med. 2015; 8(5): 7922-7929.
9. Agrawal $\mathrm{M}$ et al. Platelet Rich Fibrin and its Appliation in Dentistry- A Review Artice. National Journal of Medical and Dental Research. 2014; 2(3): 51-58.

10. Kiran NK et al. Platelet Concentrates: $A$ promising Innovation In Dentistry. Journal of Dental Science and Research. 2011; 5061.

11. Soini, Y., Paakko, P. and Lehto,V-P. Histopathological Evaluation of Apoptosis in Cancer. American Journal of Pathology. 1997; 153(4): 1041-1048.

12. Pizem, J., Cor,A. Detection of Apoptosis Cells in Tumour Paraffin Section, Radiol. Oncol. 2003; 37(4): 225-232.

13. Chen $\mathrm{B}$ et al . RANKL Expression In Periodontal Disease : Where Does RANKL Come From. Biomed Research Internasional. 2014; 731039.

14. Tanaka $\mathrm{H}$ et al. Expression Of RANKL/OPG During Bone Remodelling in vivo. Biochemical and Biophysical Research Communication. 2011; 41(1): 690-694.

15. Saima S, Jan SM, Shah AF, Yousuf A, Batra M. Bone grafts and bone substitutes in dentistry. J Oral Res Rev. 2016; 8: 36-8.

16. Choukroun Joseph MD et al. Platelet Rich Fibrin (PRF): A Second-Generation Platelet Concentrate. Part II: Platelet-related biologic features. Oral Surg Oral Med Oral Pathol Oral Radiol Endod. 2006; 1: p.E45E50.

17. Chang IC, Tsai $\mathrm{CH}$, Chang YC . Platelet-rich fibrin modulate the expression of extracellular signal-regulated protein kinase 
and osteoprotegerin in human osteoblast. J

Biomed Mater Res. 2010; 95(1): 327-32

18. Madi et al. Platelet Rich Fibrin and periodontal tissue regeneration. Adv Dent \& Oral Health. 2017; 4(5).

19. Marx R. Platelet-Rich Plasma : Evidence to supports its use. Journal Oral Maxillofacial Surgery. 2004; 62: 489-496.

20. Borie E et al. Platelet-rich fibrin application in dentistry:a literature review. Int J Clin Exp Med. 2015; 8(5): 7, 922-7929.

21. Dohan et al. Platelet-rich fibrin (PRF) : $A$ second-generation platelet concentrate.
Part I: Technological concept and evolution. Oral Surg Oral Med Oral pathol Oral Radiol Endod. 2006; 101: E37-44.

22. Anitua E, Andia I, Bruno A, Nurden $P$, Nurden A. Autologous Platelets as a source of Proteins for Healing and Tissue Regeneration. Journal Thrombosit Haemostat. 2004; 91: 4-15. 